\title{
MASTER
}

\section{Development Plan for Housing, Public Facilities and Services}

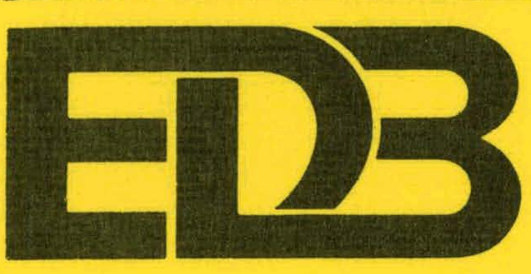

Energy Development Board of Mercer County

July 1979

10 


\section{DISCLAIMER}

This report was prepared as an account of work sponsored by an agency of the United States Government. Neither the United States Government nor any agency Thereof, nor any of their employees, makes any warranty, express or implied, or assumes any legal liability or responsibility for the accuracy, completeness, or usefulness of any information, apparatus, product, or process disclosed, or represents that its use would not infringe privately owned rights. Reference herein to any specific commercial product, process, or service by trade name, trademark, manufacturer, or otherwise does not necessarily constitute or imply its endorsement, recommendation, or favoring by the United States Government or any agency thereof. The views and opinions of authors expressed herein do not necessarily state or reflect those of the United States Government or any agency thereof. 


\section{DISCLAIMER}

Portions of this document may be illegible in electronic image products. Images are produced from the best available original document. 
Mercer County

Energy Development Board

Board Member

Robert Wetzel

Chairman

Ernie Mosbrucker

Vice Chairman

Albert Bauman

Gerald Bauman

Mel Beckler

Arnold Erbstoesser

Sharold Geist

Adolph Miller

Leonard Schmidt

Curtis Schulz

Ed Schulz

Martin Staigie

O.B. Taylor

Chip Unruh
Elected Position

Mayor

City of Stanton

Councilman

City of Beulah

Commissioner

Mercer County

Member

Mayor

City of Hazen

Mayor

City of Golden Valley

President

Hazen School Board

Commissioner

Mercer County

Mayor

City of Zap

Vice President

Beulah School Board

Commissioner

Mercer County

Member

Stanton School Board

President

Pick City-City Council

Member
Representing

City of Stanton

City of Beulah

Mercer County

Golden Valley School District

City of Hazen

City of Golden $V \varepsilon$ ey

Hazen School District

Mercer County

City of Zap

Beulah School District

Mercer County

Stanton School District

City of Pick City

Zap School District 
This Document Prepared By The:

$$
9509811
$$

\section{Staff: Mercer County Energy Development Board}

\section{P.O. Box 670, Hazen, North Dakota 58545}

July, 1979

This report was prepared as an account of work sponsored by the United States Government. Neither the United States nor the United Siater Deprartment of Energy, nor any of dieir employees, nor any of their contractors, subcontractors, or their employees, makes any warranty, express or implied, or assumes any lega liability or responsibility for the accuracy, completeness or usefulness of any informaston, upporotus, product or process disclosed, of represents that its use would no infringe privately owned rights.

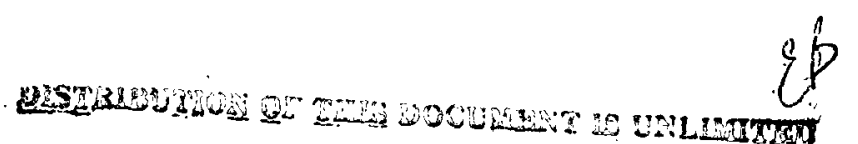


Introduction . . . . . . . . . . . . 1

Present Level of Coal Development . 5

Anticipated Level of Coal

Development . . . . . . . . 5

Description of Socio-economic

Impacts That Have Occurred . . . 6

Population . . . . . . . . . . 6

Education . . . . . . . . . 7

Employment . . . . . . . . . 7

Description of Socio-economic

Impacts Expected to Occur . . . . 9

Population . . . . . . . . . . . 9

Education . . . . . . . 10

Employment . . . . . . . . .10

Anticipated Number of New Employees

in Coal Development . . . . . . .11

Available Financial Resources and

Federal Programs . . . . . . . .12

State Assistance Expected . . . 12

Local Tax Revenues and.

Assistance Now Being

Received . .. . . . . . . .13

Existing Budget Surplus

(Deficit). . . . . . . .15

Specific Needs for Housing and

Public Facilities . . . . . . . . 17

Property Needs for Housing and

Public Facilities . . . . . . . 36

Land Acquisition . . . . . . . . .49

Estimate of Assistance ... . . . .57 


\section{Credits}

This report is the result of work accomplished by:

Deborah Prock

EDB Secretary. . . . . . . . Typing

Vivian Roehrich

EDB Office Manager . . . . . . Typing

Al DeKrey.
EDB Staff Planner . . . . . . Writing/
Editing

Bill Mrdeza

EDB Staff Planner. . . . . Writing/

Editing

John Rogers

EDB Staff Planner . . . . . Writing/

Editing

Larry Weil

EDB Planning Intern. . . . Compilation

Assistance

The preparation of this document was financed by a grant to the Energy Development Board from the Building and Community Systems Division of the U.S. Department of Energy under contract number ET-77-G-03-1619. 


\section{INTRODUCTION}

Mercer County is located in west-central North Dakota, approximately 60 miles northwest of the state capital, Bismarck. The county covers an area of 1,112 square miles and had a population of 8,282 \% in January 1979. Most of the county's small communities are strung along the Knife River and its tributary, Spring Creek, which cuts across the middle of the county. Beulah is the largest of these communities, with a population of 2,311. Hazen is the second largest, with a population of 2,199. The other communities in the county are Golden Valley, Pick City, Stanton, and Zap.

Agriculture, primarily the raising of hard spring wheat and cattle ranching, has long been the county's mainstay. Almost all the county's land is devoted to farming. Coal mining began in 1884 near Hazen and has steadily increased in importance, particularly the last decade and a half. In 1977, Mercer County produced 6.8 million tons of coal, more than 60 percent of the state's output. Agricultural employment has declined steadily, accompanying a shift in population from rural to urban areas.

The face of Mercer County will be changed radically over the next few years. Several energy supply projects and related mines have been initiated, and more are proposed (See map below). Currently, three companies mine lignite in the county. Much of this coal is used to supply the three coal-fired power plants already operating in Mercer County. However, coal production will have to expand in the next few years to supply five proposed coal-using plants. These will include the nations first coal-gasification plant, which will be located northwest of Beulah, and four additional coal-fired power plants. When these projects become operational in the 1980's, the county's generating capacity will more than triple (to approximately $2,600 \mathrm{MW}$ ) and its coal production will almost quadruple.

These energy projects will create what amounts to a population explosion in Mercer County (see following table \& figure)...... Recent estimates indicate that about 5,000 construction and operating workers will be employed in 1982. ${ }^{2}$ The resulting housing demand will double the housing stock in the County. During the early years of rapid growth, the communities will face serious deficit financing to provide expanded public services of all kinds.

Unofficial results of the U.S. Special Census, January 1979.

Inter Induatry Technical hsaistancc Tcam (ITAT), Mcrccr County Socio-Economic Impact Mitigation Assessment, Volume IV, Mercer County, January 1979, Pages 8 - 12 . 
;tablished and Proposed Energy Projects in Mercer County

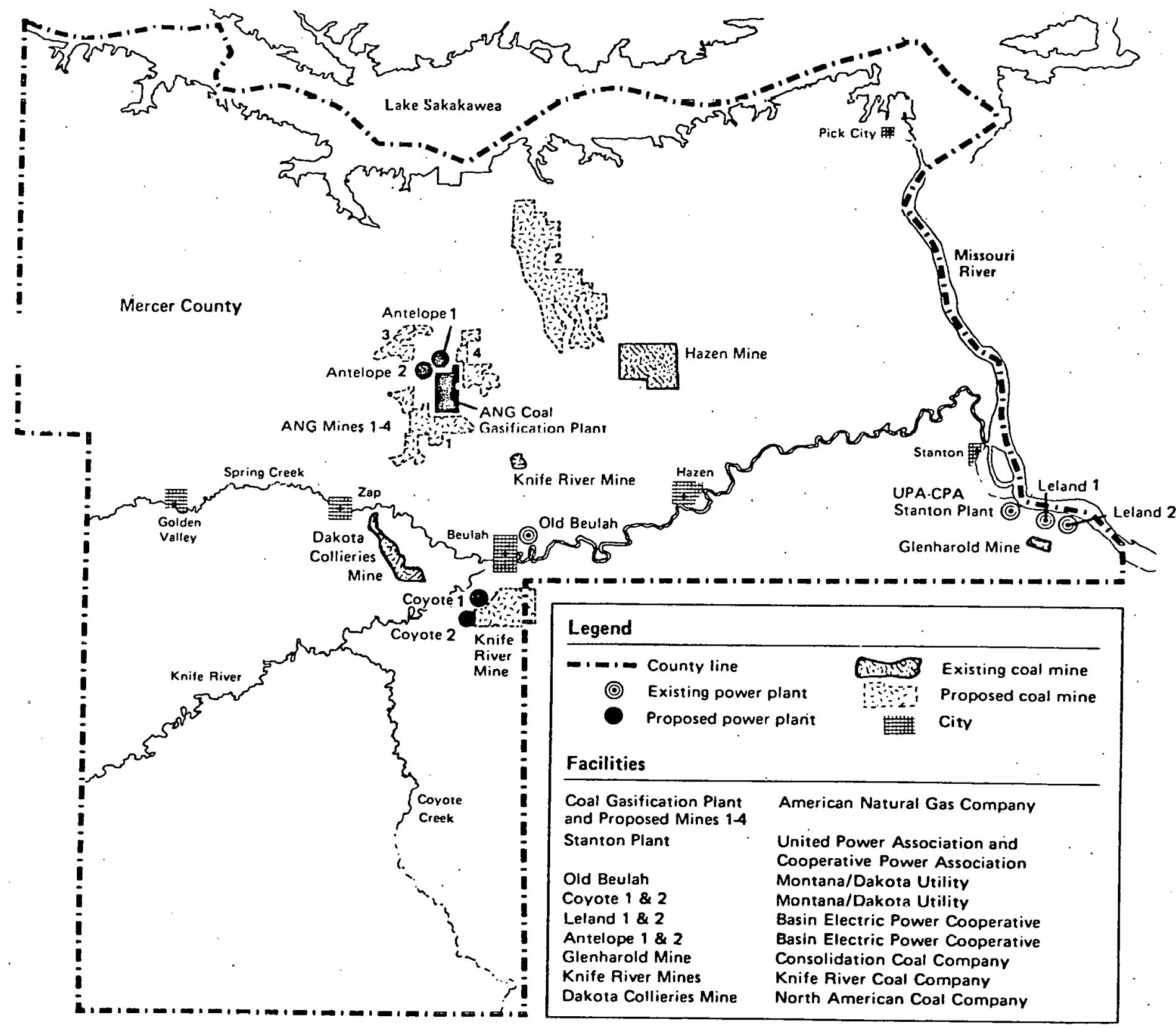


Mercer County Population Estimates, 1980-1990

$\begin{array}{lrr}\text { Year } & \frac{\text { REAP }^{1}}{\text { ITAT }^{2}} \\ 1980 & 12,387 & \text { 11,990 } \\ 1981 & 13,560 & 12,530 \\ 1982 & 11,737 & 12,570 \\ 1983 & 11,626 & 9,630 \\ 1984 & 11,509 & 9,770 \\ 1985 & 12,115 & 10,030 \\ 1986 & 12,332 & 11,600 \\ 1987 & 12,561 & 11,630 \\ 1988 & 12,115 & 10,730 \\ 1989 & 11,874 & 10,160 \\ 1990 & 11,811 & 10,160\end{array}$

1 REAP, April 1978.

2 ITAT, September 1978. 


\section{REAP and ITAT Population Forecasts}

for Mercer County, North Dakota, 1978-1990

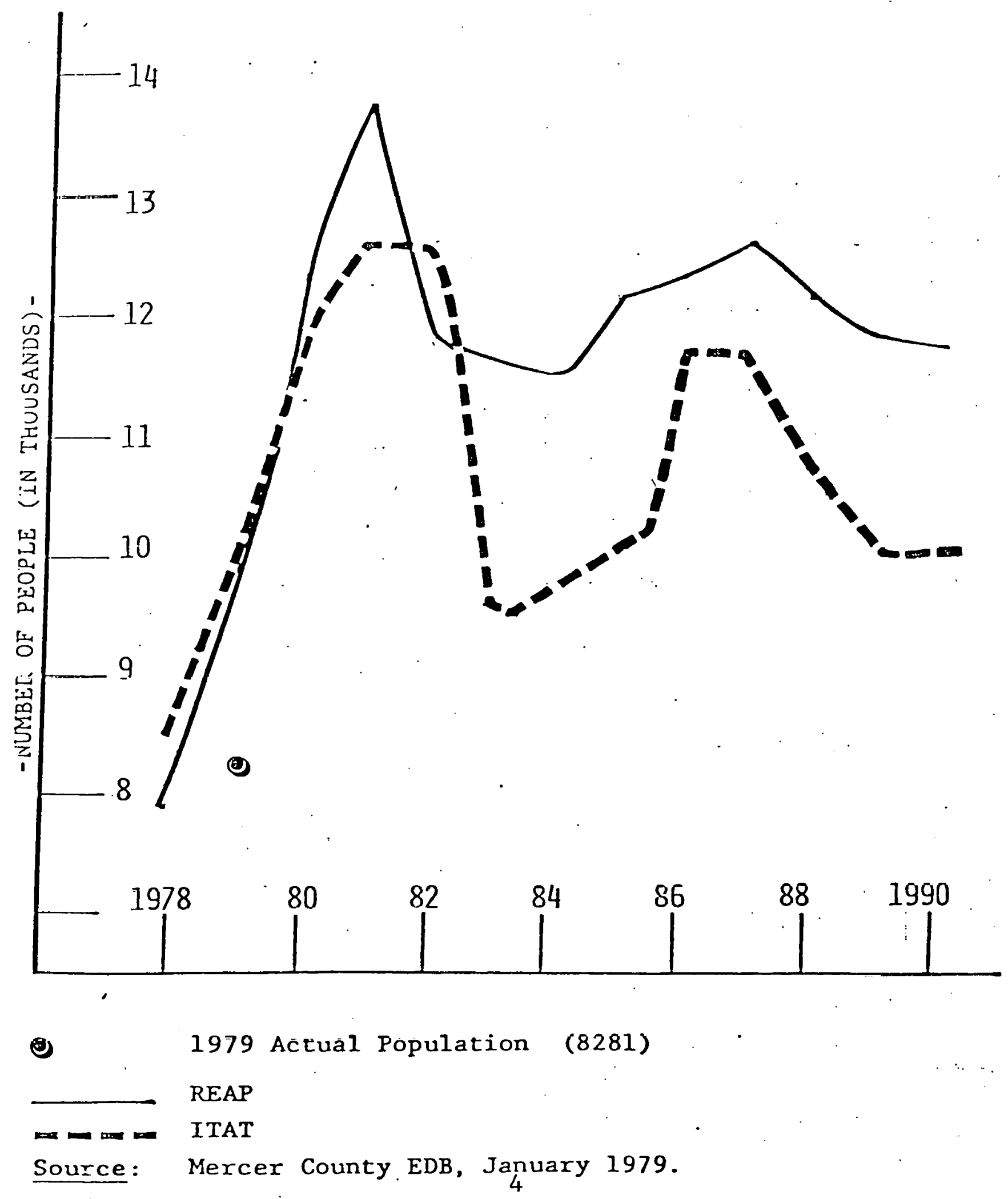


PRESENT LEVEL OF COAL DEVELOPMENT

Currently, three companies have mining operations in Mercer County; Consolidation Coal Company, Knife River Coal Company and North American Coal Company. All mine lignite and.were responsible for the 1978-1979 production figure of $5,800,818$ tons of coal.

This figure has been increasing since 1919 when the annual total Mercer County production was only 61,000 tons. Since that time, the total number of mines in the county has decreased from a high of 26 in 1936 to the present three major operating mines. Total production too has fluxuated, reaching a high of 6.9 million tons in 1977 . Dwindling reserves on company owned lands has resulted in mining cut backs, but with the anticipation of future federal leasing of coal soon to be a reality, plus the addition of more mines and conversion facilities, production is expected to drastically increase in the future.

\section{ANTICIPATED LEVEL OF COAL DEVELOPMENT}

Coal production is expected to increase in Mercer County for several reasons. First, Coteau Properties is anticipated to open another mine in the county to service both the Antelope Valley Station as well as the proposed ANG Coal Gasification Plant. The construction of additional coal conversion facllities; specifically Coyote Station, Antelope Valley Stations 1 and 2 and the ANG Coal Gasification Plant, will have much greater requirements for coal than present levels of production currently provide. Although full production is not projected for several years, increases will occur over current production levels as new plants come on line, federal coal reserves are leased and mining begins, and additional mines are opened.

It is projected that the 1980 level of coal production in Mercer County will increase to 6.5 tons, while 1981 and 1982 figures will show mining operations reaching a level of 10.6 and 14.1 tons, respectively.

4 President, North Dakota Lignite Council, from figures provided by Major North Dakota Mining Companies.

Energy Development Board. "Forecasts". Mercer County Growth Management Plan. January 1979. p. 77 .

Ibid. P. 78 . 


\title{
DESCRIPTION OF SOCIOECONOMIC IMPACTS THAT
}

\author{
HAVE OCCURRED
}

\section{Population}

The population of Mercer County has been undergoing rapid changes in the past several years. Originally an area engaged in agriculture, until recently it was plagued with the same problems which other rural areas are experiencing - a net loss in population. From a high of 9,611 persons in 1940, the county continued to experience a decline in numbers until in 1970, a net population of 6,175 was obtained. As with other rural areas, residents were leaving their farms for better jobs and increased opportunities which could be found in urban areas.

With the increase in energy development, specifically coal in Mercer County, the total county population is again on the increase. According to the latest Special Census figures, since 1970, Mercer County has increased its population by $34 \%$ with an official total of 8,282 persons. Because of special censuses in several of the incorporated cities, more recent growth rates can be examined. For instance, from 1975 to 1979, Hazen experienced a 41\% increase in growth, while Beulah experienced a similar $43 \%$ increase during the period 1977-1979. Other increases can be seen in the following table.

\section{Population Comparisons}

\begin{tabular}{rrrrrrr}
1.970 & 1975 & 1977 & 1979 & $\%$ Tnr, & $\%$ Tnr. & $\%$ Tnr: \\
Pop. & Pop. & Pop. & Pop. & $1970-79$ & $1975-79$ & $1977-79$ \\
\hline
\end{tabular}

\begin{tabular}{|c|c|c|c|c|c|c|c|}
\hline Pick City & 119 & -- & -- & 156 & $31 \%$ & -- & -- \\
\hline Stanton & 517 & -- & 583 & 614 & $19 \%$ & -- & $5.3 \%$ \\
\hline Zap & 271 & $\sim$ & -- & 347 & $28 \%$ & -- & -- \\
\hline Golden Valley & 2.3 .5 & - & -- & 276 & $17 \%$ & -- & - \\
\hline Hazen & 1,240 & 1,558 & -- & 2,199 & $77 \%$ & $41 \%$ & -- \\
\hline Beulah & 1,344 & -- & 1,611 & 2,311 & $72 \%$ & -- & $43 \%$ \\
\hline $\begin{array}{l}\text { Rural (includes } \\
\text { Fort Berthold) }\end{array}$ & 2,503 & -- & -- & 2,379 & $-5.0 \%$ & -- & -- \\
\hline Mercer County & 6,175 & -- & -- & 8,282 & $34 \%$ & -- & -- \\
\hline
\end{tabular}

7 U.S. Dept. of Commerce, Bureau of the Census. "Mercer County Special Census." January $10, \frac{1979}{6}$ 
These population increases which the county and incorporated cities have experienced in the past several years have occurred as a direct result of increased mining operations, power plant construction and power plant operation. Future population figures show even greater increases as additional coal conversion facilities are built and become operational.

The county as a whole contains more males than females for most age groups except for the 75 to $85+$ age bracket. The largest differences occur in the 20 to 39 age bracket - primarily because of the influx of construction workers and other energy related personnel. The figure below graphically breaks each age group down by its related percentage to the county population.

\section{Education}

Mercer County has a lower average for educational attainment than the state as a whole -8.6 as compared with 12.0 for North Dakota. Five school districts share the responsibility for educating county residents.

According to the projections furnished by the Regional Environmental Assessment Program (REAP) the total number of school enrollments for Mercer County is expected to increase by 328 students between 1977 and 1979. The total enrollments for 1977 were 1,542 while expected enrollments for 1979 are projected to be 2,133.9 Unlike many rural areas throughout the state, enrollments have been increasing, again the result of energy related development. Enrollments are expected to continue in this trend for the next few years.

\section{Employment}

In 1977, the total energy-related workforce numbered 475, with the majority of those being employed by the mining companies. In 1978, this figure increased to 1,198 . ${ }^{0}$ This increase in energy-related employment can be directly attributed to increased construction activity by coal conversion facilities. Currently, the 19.79 estimate of this sector of Mercer County's workforce totals. 1,9.12 workers.

State of North Dakota: Draft West-Central North Dakota Regional Environmental Impact Study on Energy Development, January 20, 19.78 .

9 Energy Development Board "Forecasts". Mercer County Growth Management Plan. January, 1979.

10 Inter-Industry Technical Assistance Team. Employment/Craft Report. February, 1979, 


\section{MALE}



FEMALE

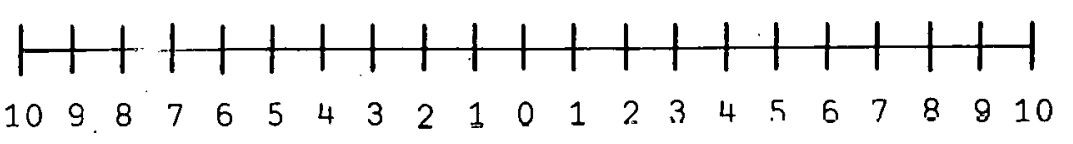

Percent of Total Population

MERCER COUNTY: 1979

Source: U.S. Dept. of Commerce, Bureau of the Census. "Mercer County Special. Census." January 10, 1.979. 
Of this figure, 393 work at mine production and processing facilities. Current projections indicate future increases will occur in this area.

Since 1970, the total employment in Mercer County rose from 2,583 persons to 3,443 in 1974. Although farming is still an important industry in the county, as a percent of total employment, it fell from $33.8 \%$ in 1970 to $24 \%$ in 1974 . 11 This can be primarily explained by an increase in the number of persons, primarily energy-related workers, currently employed in no-farm occupations in the county.

In addition to the above mentioned socioeconomic conditions, additional factors such as housing and financial status are important considerations. These topics will be discussed elsewhere in this report under a separate heading.

\section{DESCRIPTION UH SUCTOECONOMIC IMPACTS F.XPECTED \\ TO OCCUR}

\section{Population}

During the next three years, Mercer County is expected to continue to experience rapid increases in its population. The table below gives projections furnished by the Inter-Industry Technical Assistance Team (ITAT).

$\underline{\text { Year }}$

1980

19.81

1982
Total

County Population

10,865

13,435

15,570

11

State of North Dakota. Draft West-Central Regional Environmenlal Impact study on Eliegy Dcvelopment, January 20, 19.78 :

12

Inter Industry Technical Assistance Team (ITAT). Mercer County Socio-Economic Impact Mitigation Assessment, Volume IV. Pages 16-18. January, 1979 . 
Comparing the peak projected population with the current county population of 8,282 , it is evident that within the next three years the number of persons in the county is expected to almost double.

\section{Education}

According to the latest projections, school enrollment in Mercer County is also expected to experience increases in the next few years. In addition to the normal growth rate which is experienced by each individual school district the following table gives school enrollment projections based upon only, those additional students associated with energy-related development.

$\underline{\text { Year }}$

1980

1981

1982
Projected County School Enrollment Caused by Energy-Related Development Only

$$
2,102
$$

2,455

2,819

Employment

Projections for the number of persons engaged in agriculture in Mercer County are currently unavailable. It can be assumed that for the next three years, Lhe number will remain fairly constant with little change associated with this area. The number of farmers as a percentage of total employment in the county will decline, however, because of expected increases in those persons working in the energy-related industry.

According to recent estimates, the total number of employees working at area mines and coal conversion and coal handling facilities (both construction and operational) is expected to experience large increases. The table below shows these increases by year.

Ibid.

4 Tnter-Industry Teohnical $\Lambda$ ssistance Tedll. Ellployment/Crät Report. February, 1979 . 
$\underline{\text { Year }}$

1980

1981

1982
Total Number of Energy-Related

Industry Workers

The large increases in the energy related work force are primarily related to the construction and operation of the Coyote Project, the construction of Antelope Valley Station (AVS) Units 1 and 2, and the construction of the nation's first commercial coal gasification plant. In addition, Coteau Properties are in the process of opening up another mine in order to serve both the AVS and Coal Gasification plant sites.

\author{
ANTICIPATED NUMBER OF NEW \\ EMPLOYEES IN COAL DEVELOPMENT
}

The total number of additional employees associated with energy-related development have been discussed in the previous section. Of those numbers, a certain portion of the total workforce is engaged primarily in mine production and processing facilities. Like the total workforce projections, the numbers associateld with this sector of the workforce also indicate increases in the next three years. The table below indicates the increases that can be expected only at the mine production and processing facilities.15

$\underline{\text { Year }}$

1980

1981

1982
Projected Number of Workers Employed $\Lambda t$ Minc Sites
1,151

2,448

3,955 


\section{AVAILABLE FINANCIAL RESOURCES}

AND FEDERAL PROGRAMS

\section{State Assistance Expected}

North Dakota's Coal Severance'Tax Law became state law after the 1975 Legislative Session. Since that time, the allocation formula for appropriating severance tax revenues has been changed to the following distribution formula: 20 percent is returned to the counties from which it was collected, 35 percent to the Coal Development Impact Office, 15 percent to the State Land Board and 30 percent to the State General Fund. Of the 20 percent received by the county, 40 percent remains with the county, while the remaining 60 percent is divided among the cities and the schooi districts ( 30 percent each).

During calender year 1977, the State of North Dakota collected and distributed $\$ 7,369,194.72$ in Coal Severance Taxes. Approximately

$11,205,783.25$ was collected and distributed in 1978.15 Currently, Po, 200,000 has been appropriated to the Coal Development Impact Office for fiscal year 1979-80. The Coal Severance Tax currently is collected -at a rate of $85 \mathrm{c}$ per ton, with a lc increase for every four point rise in the wholesale price index.

The state also collects a Coal Conversion Tax at the rate of 2.5 mills per kilowatt hour of electricity generated. The money generated by this tax is appropriated: 35 percent to the county in which the power was generated and 65 percent to the State General Fund. Again, of the 35 percent received by the county, the county retains 40 percent, while the incorporated cities receive 30 percent and the school districts 30 percent. 17

During fiscal year 1977-78, $\$ 2,133,990.68$ in Coal Conversion Taxes were collected and distributed by the State. From July 1, 1978 to March $31,1979, \$ 1,640,476.58$ was collected by the state in Coal Conversion Taxes.18

North Dakota State Planning Division. Request for Designation Under Part 1948 - Rural Development Act, Subpart B, Section 601: Energy Impact $\Lambda$ rea Development Assistanre Program. 


\section{Local Tax Revenues and Assistance}

\section{Now Being Received}

The following two tables indicate the amount of revenues which the county and the cities within the county can expect to collect during the period 1979-1982.19,20

\section{Mercer County}

\section{Revenue Projections}

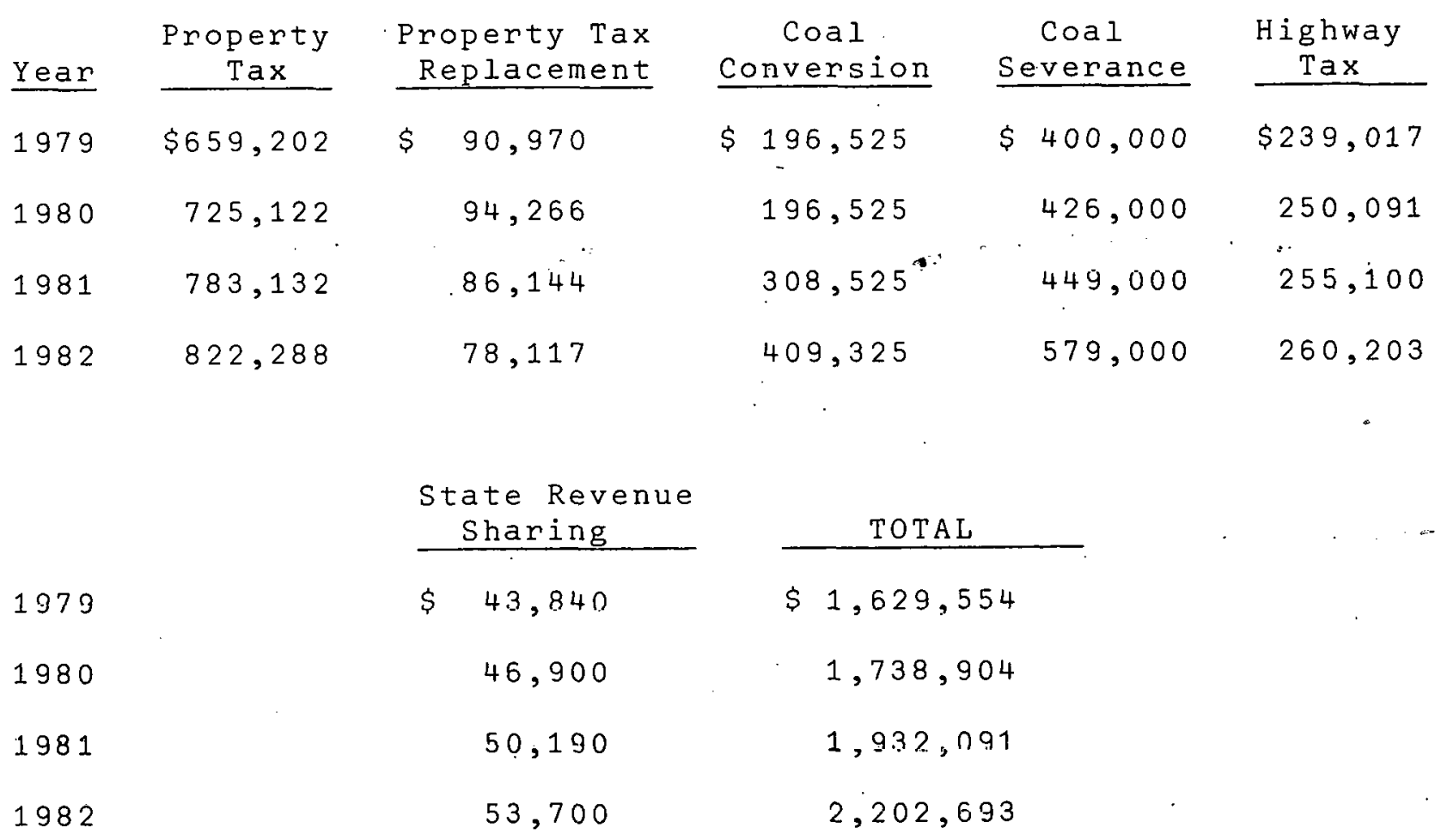

19 Larry Weil. Mercer County Energy Development Board. Coal Severance and Coal Convereion Tax Projestions for Mercer County. June; 1979.

20 William Mrdeza \& John Rogers. Mercer County Energy Development Board. Revenue Projections for Mercer County and Incorporated Cities. March, 1979. 


\section{Mercer County Incorporated}

\section{Cities. ${ }^{21}$ Revenue Projections}

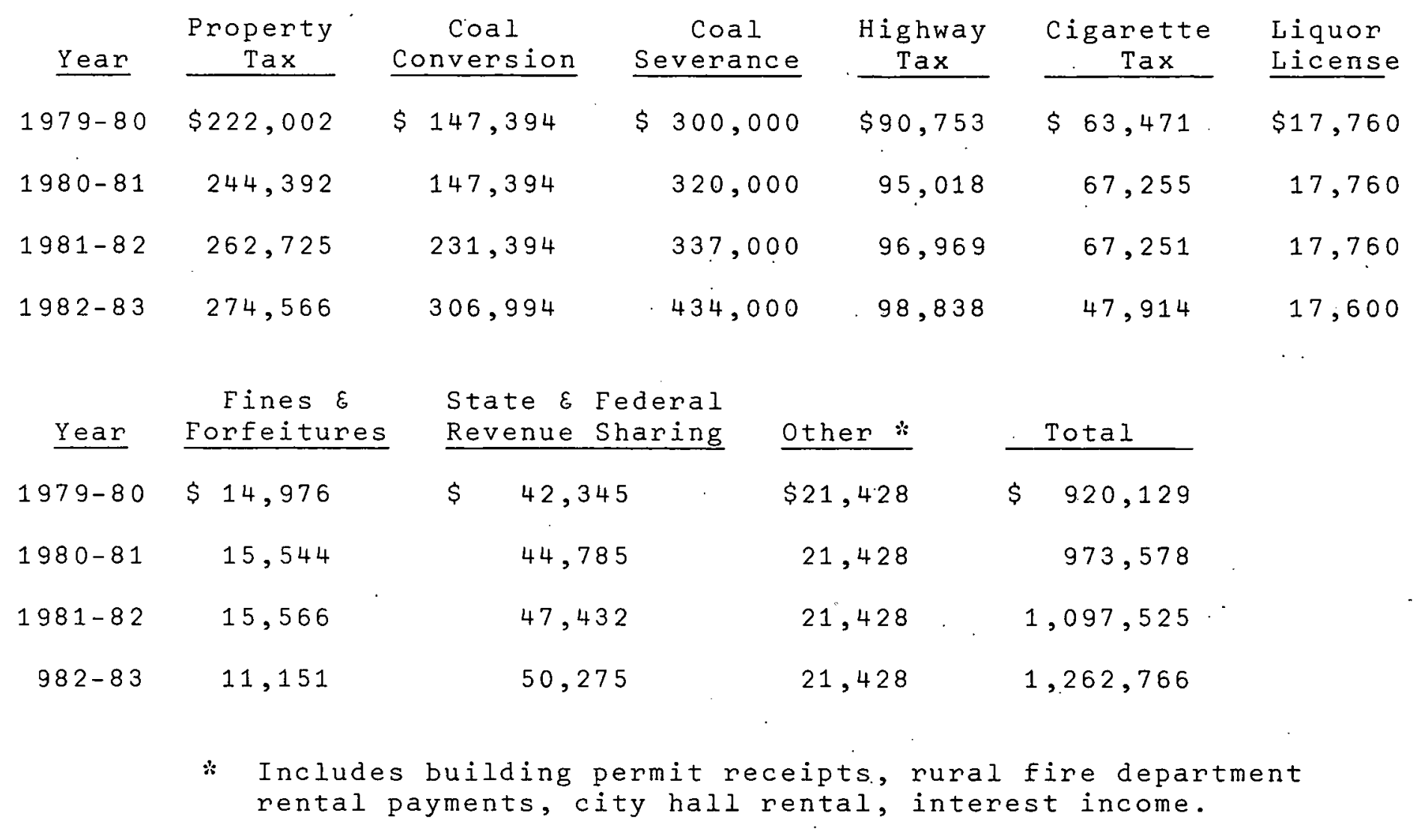




\section{Existing Budget Surplus (Deficit)}

The following two tables show the projected fiscal balance which is expected to occur in both the county and the six incorporated cities. 22 These figures were derived by comparing the projected expenditures with expected revenues from the previous table. Projected expenditures include proposed capital expenditures which were identified by the local governments as high priority items. In addition, operating expenditures were projected by observing historical operating costs for the local governments and carrying these out over the projection period. A full discussion of the proposed capital expenditures for each of the local governments is contained in later sections of this report.

Mercer County

Projected Fiscal Balance 1979-1982

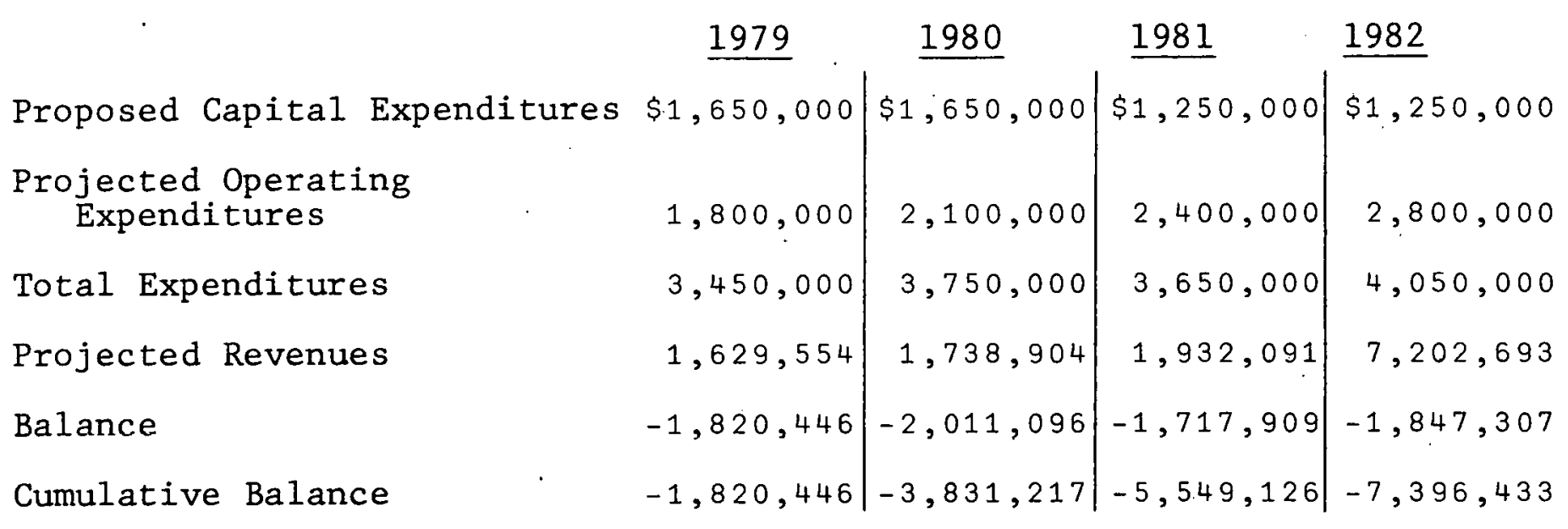

22

Mercer County Energy Development Board. Public Investment Strategies for Mercer County and Incorporated Cities. June, 1979. 


\section{Mercer County Incorporated Cities' Projected}

Fiscal Balance 1979-82

\section{Fiscal Yeats}

$1979-80 \quad 1980-81$

Proposed

Major

Expenditures $\$ 3,245,000 \$ 978,500$

$\$ 1,853,500 \quad \$ 968,000$

Operating

Expenditures

$997,876 \quad 1,056,882$

$1,148,638$

$1,217,794$

Current

Tndebtedness*

$30,500 \quad 30,500$

30,500

30,500

Total

Expenditures

$4,273,376 \quad 2,065,882$

$3,032,638$

$2,216,294$

Projected

Revenue

920,129

973,578

$1,09.7,525$

$1,262,766$

Balanse

$-3,353,247-1,092,304$

$-1,935,113$

$-953,528$

Cumulative

Balance

$-3,353,247 \quad-4,445,551$

$-6,380,663) \quad-7,334,132$

* Repayment of North Dakota state Land Board Loan for the City Hall addition and Fire Hall/Law Enforcement Building. 


\section{SPECIFIC NEEDS FOR HOUSING AND PUBLIC FACILITIES}

The City of Beulah

Housing Needs

The City of Beulah is currently keeping up with the demand for housing. One mobile home court will be completed in the fall of 1979 and will fill a need for lots to locate mobile homes on. Two new single family housing subdivisions recently began construction. These subdivisions will provide an additional seventy-five lots for development. However, in the next three years the following units will be required to meet the demand for housing.

Housing Needs Estimates According to the North Dakota

Regional Environmental Assessment Program (REAP)

$\begin{array}{ccccc} & \begin{array}{c}\text { Projected Dwelling } \\ \text { Units Total }\end{array} & & \begin{array}{c}\text { Annual } \\ \text { Change } \\ \text { or N Need }\end{array} \\ 1979 & 968 & & & \text { Change } \\ 1980 & 1,077 & -- & -- \\ 1981 & 1,236 & 109 & 10 \% \\ 1982 & 1,405 & 159 & 13 \% \\ 19 & 1,409 & 16 \%\end{array}$

Source: Regional Environmental Assessment Program. EconomicDemographic Model Output, Version W4. December 1978. Bismarck, N.D.

While present construction projects are nearly keeping up with the demand for new housing, indications are that a great deal more housing will be required through 1982 in Beulah. 
Public Facilities Needds

The following public facilities will be needed in the next three years in Beulah:

Dry Dams. The general terrain on the north side of the city is sloped from the north to the south side of Beulah which is bordered by the Knife River. On the north side of Beulah are four main drainage areas which eventually drain runoff through the city. In the past, the city has experienced flash floods through the city as a result of heavy rains. It is feared that these conditions may be accelerated since nearly all of the urban expansion of the city has occurred on the north side in the drainage and runoff area. The urban development in that area has tended to accelerate the runoff volume and velocity into the center of the city. In order to improve the drainage in the center of the city, funds have been secured to install storm sewers in the Central Business District. In order to alleviate additional problems from rapid runoff, four drydams. or holding ponds are needed to hold runoff for regulated discharge to the Knife River. Any of these four drydams would improve the flooding situation in the city. Therefore, the drydams could be constructed separately. One drydam would also provide a street crossing for 10th Street North which would connect the east and west sides of the city. The total cost of construction of all four drydams is estimated at $\$ 1,100,000$.

Bike Path. As the city has grown, many facilities were not affordable at the time of initial development. One residential development on the northeast side of the city is separated physically from the rest of the city by a drainage ditch (discussed above). This ditch does not provide access for pedestrians and bicyclists from this area to the rest of the city. The only access is by county road 非1. The traffic on this road has increased $400 \%$ from ten years ago. The lack of access has forced cyclists and pedestrians to use county road 非21 thereby creating a safety hazard. Phase I. of the Beulah Bikepath projert. would include construction of a Bikepath from this new residential subdivision thence parallel to Seventh Street North to the Beulah School. The approximate length of this bikepath would be 1200 ft. The estimated total cost of Phase I is $\$ 52,000$. Phase II of the Beulah Bike System Plan would extend a bikepath from the end point of Phase I to the south accross the Knife River to a new residential subdivision which is now under construction. The Phase II cost esti-:! mates have not been developed at the time of this writing.

Storage and Maintenance Facility. The city has had to acquire additional equipment to provide expanding services in the city as a result of its growth. In the past two years, the city has added a new street sweeper, a new garbage truck, and snow removal equipment. Consequently, the city is running out of space to store and maintain this equipment. Therefore the city needs to construct a storage and maintenance facility. The estimated cost of this facility is $\$ 250,000$. 
Neighborhood Playgrounds. The Beulah Park Board does not receive funds for development from Coal Conversion and Severance Taxes. In spite of this, it is required to meet the recreational needs of the community. While it has been able to construct many community-wide facilities, it has not been able to provilde neighborhood playgrounds in new residential areas. Neighborhood playgrounds are required in areas that are secluded from the other parts of the city and that do not presently have them. Three playgrounds are needed at an estimated cost of $\$ 60,000$.

Parking Lots. As a result of growth in the Beulah Central Business District, a lack of parking areas exists. A recent parking survey conducted by the Mercer County EDB revealed that parking spaces in the Central Business District experienced over 95\% occupancy from 3:00 p.m. to $5: 30 \mathrm{p} . \mathrm{m}$. on weekdays. On many afternoons, cars are forced to park in neighboring residential areas. The Central Business District currently needs two parking lots at an estimated cost cí $\$ 80,000$.

Softball Diamonds.. The city is currently experiencing a "boom" in softball leagues in the city. Currently, only two softball diamonds exist to meet the needs of two softball leagues. Therefore, the city needs to construct two diamonds of an estimatad cost of $\$ 90,000$.

Water Line Extension South of Beulah. The city of Beulah needs to extend its municipal water lines across the Knife River to the south end of the city. Currently, a single family residential subdivision is under construction south of the city. Also the line would provide municipal water service to the South Beulah Park and the Municipal Golf Course. The provision of this water line would open more land for development and would contribute to the orderly growth for the city. The estimated cost of this project is $\$ 100,000$.

Hockey Rink. In order to more fully address the winter recreation needs in the community, the city needs to construct a hockey rink. Presently there are none in the city. The estimated cost of this project is $\$ 40,000$.

Joint Airport. The city's present airport facility is inadequate to handle current demands. It has inadequate taxi and parking facilities, a runway of only 2500 feet, and the existing runway is in need of repair. Rather than to upgrade the existing airport however, Beulah has undertaken a study in cooperation with the City of Hazen to study the feasibility of constructing a joint airport facility. This facility would be located almost half way in-between the two cities. It is 
felt that a joint facility is more expedient for both communities. The runway would be approximately 4800 feet long and would accomodate small corporate jet aircraft as well as small commuter aircraft. The preferred site that was chosen is in an area that was previously undermined and is in need of reclamation. The estimated cost of this project is $\$ 2,700,000$.

Golf Course Improvements. The Beulah Municipal Golf Course is in need of an irrigation system and grass greens. The estimated cost of this project if $\$ 100,000$.

Improvements at Beulah Bay. The Beulah Park Board has leased land from the Corps of Engineers at Lake Sakakawea for a regional recreation area. At this time, the city does not have funds available to make necessary improvements in this area. RV pads, boat docks, roads, and picnic shelters are needed to more fully developthis area. The estimated cost of these improvements is $\$ 100,000$.

Additional Water Storage. The city's current water storage capacity will accomodate a population of approximately 4500 persons. However, the city is projected to grow to approximately 6000 persons by 1982 . Therefore, the city needs to increase its water storage capacity at an estimated cost of $\$ 600,000$.

Highway Overpass. A highway overpass is needed on Highway 49 in the center of the city on the North Branch Burlington Northern Railroad Line. Coal trains cause traffic congestion in the city and may cause a hazard at times when ambulances or fire trucks cannot cross. The estimated cost of this project is $\$ 2,000,000$. 
SPECIFIC NEEDS FOR HOUSING AND PUBLIC FACILITIES

City of Golden Valley

Housing Needs

The city of Golden Valley will need many additional housing units in the next three years. Most of this need will be for mobile homes. The following projections are provided:

$\begin{array}{cccc}\begin{array}{c}\ddots \\ \text { Year }\end{array} & \begin{array}{c}\text { Total Need } \\ \text { in Households }\end{array} & \text { Change } & \text { \% Change } \\ 1979 & 107 & - & - \\ 1980 & 129 & 22 & 17 \% \\ 1981 & 160 & 31 & 19 \% \\ 1982 & 193 & 33 & 17 \% \\ \text { Source: Inter-Industry Techrical Assistance Team. Mercer County } \\ \text { Socioeconomic Impact Mitigation Assessment, Volume IV. } \\ \text { Janury 1979. Bismarck, N.D. }\end{array}$

This housing will accomodate a projected population of 521 by 1982 .

Public Facilities Needs

Street Paving. Currently, none of the city streets are paved. This situation causes many detrimental effects on the city such as erosion during rainstorms, excessive dust during dry periods and high maintenance costs. The estimated cost of this project is $\$ 520,000$. 
Community Center. The city currently does not have adequate meeting facilities for local activities as well as municipal council meeting. Therefore, the city needs to construct a community center at an estimated cost of $\$ 200,000$.

Waste water Treatment Facility. The city will need to expand its waste water treatment facilities to accomodate additional population. The city needs to add a primary cell in addition to its existing two cells. The estimated cost of this project is $\$ 80,000$.

Basketball and Tennis Courts. The city currently does not have these facilities. There is a need to construct one tennis court and one basketball court in the city of Golden Valley at an estimated cost of $\$ 60,000$.

Sidewalk Improvements. Sidewalks are needed in most residential areas of the city to provide good pedestrian access throughout the city. The estimated cost of this project is $\$ 80,000$. 


\section{SPECIFIC NEEDS FOR HOUSING, PUBLIC FACILITIES \\ AND PUBLIC SERVICES \\ City of Hazen}

Housing Needs

Hazen is being impacted by coal development. Housing statistics contained in the "Homes" section of Hazen Tommorrow, A Plan, illus-. trated the growth. A total of 494 housing were recorded during the 1970 census, prior to the boom. Since then, the number of housing units has increased by more than 70 percent to 840 , as counted in a January 1979 Special Mercer County U.S. Census. In 1978 alone, approximately 150 housing units were added to the community's housing supply. Building is continuing at a rapid pace this construction year. The following table indicates that the tremendous rate of building evident in the recent past is expected to continue for the. . next three years.

\section{City of Hazen Housing Estimates}

Year

1970

1979

1980

1981

1982
Total

494

840

1,110

1,287

1,324

Source: North Dakota Regional Environmental Assessment Program (REAP) Bismarck, N.D. April, 1978.

Public Services and Facilities

The table indicates that during the next three years, almost 500 additional housing units wi.1. be needed in Hazen to accomodate the impact of coal development. As would be expected, the magnitude of this growth will result in the community facing serious deficit financing attempting to respond to demands for expanded public facilities and services. 
A fiscal analysis contained in the "Dollars, the Bottom Line" section of Hazen, Tommorrow, A Plan, indicates that the deficit for the city of Hazen will approach one million dollars by fiscal year 1983. This analysis was based upon a list of priorities developed by the Hazen City Commission for the various projects that have been proposed. The following are projects that have been identified as priorities by the City Commission.

West Hazen Access Road and Drainage Improvements. Because of the floodplain, much of the new growth in Hazen has taken place to the north and west. The result has been the development of subdivisions with very poor access between them. At the present time there is only one access road between the new growth areas to the north and the older parts of town. After the completion of the Hazen Highway Bypass currently under construction, the intersection of this access road and the bypass will pose a serious traffic problem. To alleviate traffic pressure at this intersection, a West Hazen Access road has been proposed to link several of the new growth areas and provide an improved transportation network. A second access road is needed bordering the northern edge of the largest new subdivision. A second portion of this project concerns drainage improvements. Spring runoff and heavier rainfalls are creating a serious water runoff problem in the larger new subdivision. As a part of the West Hazen Access Road Project, a municipal drainage ditch has been proposed to be constructed to divert runoff around the subdivision and into a creek bordering the subdivision on the south. In addition, it has been proposed that storm sewers be installed along the northern edge of this subdivision to prevent the remainder of the runoff from flooding the subdivision. .9 of an acre will need to be acquired for the access road construction.

Downtown Parking Improvements. Coal development in Mercer County has created a serious traffic problem in the downtown area. To help alleviate this traffic pressure, a highway bypass is currently under construction. The completion of this project will have a devestating effect on the downtown business district. Many business persons have indicated that because of a lack of parking space, they will move their businesses to areas along the bypass. To encourage business persons to stay in the downtown area, it has been proposed that several municipal parking lots be constructed. This project would involve the acquisition of four lots, demolition of four delapidated structures, and site improvements at these areas.

Bike Trail Development. With the completion of the Hazen Highway Bypass Project, four new subdivisions will be linked. As the bypass will be the shortest access between these housing developments, pedestrians and bicyclists will also be heavily using this roadway. The result will be a very dangerous mix of cars, trucks, bikes, and kids. The North Dakota Highway Department has recognized the seriousness of the problem and is including a portion of a separate bikeway as part of the bypass project. It has been proposed that the remainder of the separate bikeway along the bypass be completed. 
West Hazen Sewer Bypass.: It is expected that the new development to the west will overload the sewage main serving the older part of the city. It is also anticipated that additional development will occur in this area, further aggravating the problem. A West Hazen Sewer Bypass has been proposed to collect the sewage from the new developments to the west, cross the highway bypass, and join a large force main serving the new housing areas to the north. .4 of an acre of easements will be required for construction of this project.

Sewer Main Replacement. As a consequence of diverting sewage from the new subdivisions to the west, improvements in the main lift station will be necessary to adequately handle the increased flow.

City Landfill Development. The City of Hazen is in the process of studying the feasibility of a municipal garbage service and landfill operation. If the decision is reached to proceed with such an operation, a city landfill would be required. This project would involve the acquisition of approximately two acres and site improvements.

Additional City Well. This project will provide the city with a dependable and adequate supply of water.

Completion of Water, Sewer and Streets in New Subdivisions. This project involves the extension of water and sewer mains and street paving for two new subdivisions partially developed. The project would complete city improvements in these areas.

Joint Airport. Rather than upgrade the existing airport, Hazen has undertaken a study in cooperation with the city of Beulah to study the feasibility of constructing a joint airport facility. 'l'his facilily would be located half way in-between the two cities. It is felt that a joint facility is more expedient for both communities. The runway would be approximately 4800 feet long and would accomodate small corporate jet aircraft as well as small commuter aircraft. The preferred site that was chosen is in an area that was previously undermined and is in need of reclamation. The estimated cost of this project is $\$ 2,700,000$. 
SPECIFIC NEEDS FOR HOUSING PUBLIC FACILITIES,

AND PUBLIC SERVICES

Pick City

Housing Needs

Pick City is being impacted by coal development. An official Special U.S. Census completed in January of 1979 indicated that the population of Pick City increased $31 \%$ from the 1970 census. Results of the Special Census show that $50 \%$ of the work force in Pick. City is employed in energy related industry, the highest percentage in Mercer County. Because Pick City is strategically located in relationship to coal development occurring in two counties, it is expected that this steady growth rate will continue.

\section{Public Services and Facilities}

The growth from coal development activities has resulted in the community facing serious deficit financing in order to respond to demands for expanded public facilities and services: A fiscal analysis contained in the "Dollars, the Bottom Line" section of Pick City Tomorrow, A Plan, indicates that the deficit for Pick City will be more than $\$ 150,000$ by fiscal year 1983 . This analysis was based upon a list of priorities developed by the Pick City Council for the various projects that have been proposed. The following are projects that have been identified as priorities by the City Council.

Street Grading and Paving. Pick City is presently serviced by an inadequate street system. City streets are poorly graded and poorly surfaced. A street grading and paving project has been proposed to provide safe, adequate and convenient streets for the residents of Pick City. Such a project would also correct a drainage problem resulting from poorly constructed city streets.

Sewer and Water Lines to New Areas. Several blocks in Pick. City could be developed for housing if city water and sewer were available. ever, at this time, money is not available to extend city mains. This project would allow for the growth of Pick City to continue by providing water and sewer service to these areas. 
City Shop and Offices. At the present time, Pick City has no storage space for city vehicles. The city recently purchased a road maintainer, fire truck equipment, and is involved in negotiations for a fire truck. A city shop would protect these vehicles and also allow for a maintenance area. A small office area would also be constructed as a part of this project.

Recreation Facilities. Pick City has no recreation facilities. The city would like to develop a basketball court, playground area, ice skating rink, tennis courts, and a softball field. 
SPECIFIC NEEDS FOR HOUSING, PUBLIC FACILITIES,

AND PUBLIC SERVICES

City of Stanton

Housing Needs

Stanton is being impacted by coal development. An official Special U.S. Census completed in January of 1979 indicated that the population of Stanton increased by $19 \%$ from the 1970 census. Because an additional boiler is being added to an electrical generating plant five miles south of Stanton, it is expected that this growth will continue. The following table records housing estimates for Stanton for the next three years.

\section{City of Stantion Housing Estimates}

$\underline{\text { Year }} \quad \underline{\text { Total }}$

$1979 \cdot 229$

1980

1981258

$19.82 \quad 258$

Source: North Dakota Regional Environmental Assessment Program (REAP), Bijsmarck, N.D. December 1978 .

\section{Publi.c. Services and Facilities}

The growth: from coal development activities has resulted in the community facing serious deficit financing in order to respond to demands for expanded public facilities and services. A fiscal analysis contained in the "Public Investment Strategy, Stanton", indicates that the deficit for Stanton will be more than $\$ 600,000$ by fiscal year 1983 . 
This analysis was based upon a list of priorities developed by the Stanton City Commission for the various projects that have been proposed. The following are projects that have been identified as priorities by the City Council.

City Shop/Offices. The city at present has no storage or maintenance facility for city vehicles. In addition, the existing city office houses all city departments. A building is needed to provide space for city vehicles and allow for separate city offices.

Pump/Motor for North Lift Station. A backup pump/motor combination is needed for the city's north lift station for use during repairs to the main pump/motor and during emergencies.

Modify Electrical Supply. Stanton operates on municipal power purchased from the rural electrical cooperative. The system is at present badly overloaded and is in need of improvements. A larger transmission line and modified substation are needed to continue supplying power to city residents.

Second City well. For safety and health purposes, a backup city well is desired.

Expansion of Water and Sewer. The development in Stanton has nearly exhausted the supply of available lots within the city. To accomodate additional growth, the city's boundaries will need to be expanded. Because land to the east is floodplain, land to the north is owned by the Natinnal Park Service, and land to the south is undesireable, land to the west is the only area for expansion. In order for expansion to occur in this area, water and sewer mains must cross a state highway and railroad tracks, an expensive proposition. This project has been proposed so that developments in the planning stages can be provided with municipal water and sewer.

Increase Size of South Lift Station. Much of Stanton's new growth has occurred in the southern part of the city. The south lift station is undersized and cannot handle additional flows. Modifications are essential in order to provide property for sewage collection. 
SPECIFIC NEEDS FOR HOUSING AND PUBLIC FACILITIES

$$
\text { City of Zap }
$$

Housing Needs

In order to accomodate an expected population of 690 persons by 1982 , more housing units will be needed each year. The city currently has a large mobile home court which began occupancy last fall, now has only about 25 lots left. This is the only vacancy within the city. The following shows projected housing requirements through 1982:

$\begin{array}{lccc}\text { Year } & \text { Total } & \text { Change } & \text { \% Change } \\ 1979 & 153 & -- & -- \\ 1980 & 191 & 38 & 20 \% \\ 1981 & 230 & 39 & 17 \% \\ 1982 & 282 & 52 & 18 \%\end{array}$

This rapid increase will require additional municipal services and facilities to accomodate these additional households through 1982.

\section{Public Facilities Needs}

Waste Water Treatment Facility. The city's Lagoon System is designed to serve a population level of approximately 190 persons. Presently, the population of Zap is over 400. At times, the present facility has been so overfilled that if has seriously threatened a bank erosion and subsequent accidental drainage of raw sewage into the Spring Creek. The City needs to add a primary cell to the two existing cells to accomodate expected population levels. The total estimated cost of this project is $\$ 105,000$. 
Municipal Water Supply We11. The city currently does not have adequate ground water supplies through its existing wells to provide water for projected populations. The estimated total cost of this project is $\$ 110,000$.

Community Center and Storage Facility. The City of Zap does not have a facility that it can use for public meetings and community activities. The city council presently is conducting its meetings in the fire hall. In addition, the city needs to construct facilities to store and maintain city equipment. City equipment is stored outside and is difficult to maintain as a result. Therefore, the city needs to construct a facility to accomodate both facility needs at an estimated cost of $\$ 250,000$.

Softball Diamond. The city needs to develop a softball diamond to improve its recreation facilities. The city does not presently have a softball diamond. The estimated cost of this project is $\$ 30,000$.

Flood Control Project (Bank Stabilization). The City needs to alleviate problems caused by spring flooding of the Spring Creek which bisects the City. This project would entail installing rip-rap on the banks at Spring Creek near lift stations and other public facilities. Damages in the 1978 Spring Flood were estimated at more than $\$ 12,000$. The estimated cost of this project is $\$ 25,000$.

Skating Rink. The city of Zap does not have a skating rink. A new skating rink needs to be constructed to help meet the city's winter recreation needs.

Sidewalk Improvements. Sidewalks are needed throughout the residential areas of the city to provide access to all areas of the city for pedestrians. This project is needed to alleviate a potential safety hazard caused by pedestrians using public streets. The estimated cost of this project is $\$ 20,000$.

Water Treatment Plant. The city will need a water treatment plant within the next three years in order to upgrade the quality of the municipal water supplies. The estimated cost of this project is $\$ 250,000$. 
SPECIFIC NEEDS FOR HOUSING, PUBLIC FACILITIES

AND PUBLIC SERVICES

Mercer County

Housing Needs

Political subdivisions within Mercer County have adopted the concept of "expanding cities". This growth management policy mandates that growth occurs within existing cities and not randomly throughout the county. Consequently specific needs for housing have been addressed in the individual city sections.

\section{Public Facilities and Public Services}

Human Services Center. Currently, Mercer County residents do not have a central location within the county to go to receive assistance in such areas as Mental Health and Retardation Low Cost Public Health Services, Welfare payments and claims, Medical Referrals, Vision and Hearing Screenings, and Counseling. Instead, the agencies that handle these fundtions - County Social Services, the Public Health Nurse, Memorial Mental Health and Retardation, and Mercer-Oliver Special Education are scattered around various cities in the county. This situation hampers coordination and contributes to confusion of the general public. Service delivery for all of the above agencies can improve with a central location. The specific reasons for co-locating Social Services are as follows:

a. Accessibility to the public health nurse, mental health worker, and police for consultation, referrel, and planning.

b. Clientele can be referred immediately to other appropriate personnel. (eg. public health nurse).

c. Better overall service delivery to agency clientele as often. as clients require or wish the services of more than one agency.

d. Opportunity for potential clientele to locate and become aware of the services of the Social Service Agency.

The lack of a co-located building works to the opposite of the above points. Distanse also hampers service delivery and at present is a big factor in adequately providing services to county residents. County Social Services personnel must now commute almost daily to Hazen, Beulah, and Zap where most clientele live. Because of these 
distances, coordination between agencies is also a problem - at times Public and Mental Health offices are not available even by phone.

According to County Social Services, caseloads increase an average of $7 \%$ of the population increase. The impact on social service resources caused by this increase, can vary according to the nature of the case. For instance, the increase of $20 \%$ in food stamp cases is tolerable, while a similar increase in child abuse/neglect, foster care, and similar cases could cause a devastating effect on the agency's financial and personnel resources. Thus, it is important to make the most efficient allocation of those social services offered to county residents, especially in an area which is growing as rapidly as Mercer County.

The recent 1979 Mercer County Special Census indicated that the County has experienced a $34 \%$ increase in population from the period 19.701979. Individual cities such as Hazen and Beulah have experienced a much greater rate of increase for that same period - $77 \%$ and $72 \%$ respectively.

A large portion of this growth has been directly related to the energy industry within the county. Of those identifying their occupation, $34 \%$ of the county residents indicated that they were employed in energy industry related activities. Of the Beulah residents responding, $44 \%$ indicated employment in the energy industry, while $35 \%$ of the Hazen respondents were engaged in similar occupations. With the County population expected to almost double in the next three years, 1 caseloads will also increase along with it. Just this past year, the Oliver-Mercer Special Education program experienced a caseload increase of $21 \%$, while the Public Health Nurse's office experienced an increase of $25 \%$ for the same period. Without proper coordination and communication between the involved organizations, the quality of social services in the county will only decline as population and caseloads increase. By combining these agencies into a common building, services can be coordinated and more efficiently allocated, thus allowing the projected increased caseloads to be handled with little loss of service quality.

The proposed facility would contain approximately 10,800 square feet of space. The most probable location would be adjacent to the Mercer County Court House in Stanton. Located here, the personnel involved. in health services delivery would have ready access to county resources and be easily accessible to all county residents.

1

Inter-Industry 'lechnical Assiștance Team, Mercer County SocioEconomic Impact Mitigation Assessment, Volume IV, January 1979, page 14. 
County Jail. This facility is intended to house an expanded facility for the Mercer County Sheriff's Department, as well as several administrative offices. Increased pressures caused by a growing Mercer County population have made present facilities obsolete and have caused crowded working conditions for many county offices. Under present circumstances, service to Mercer County residents is at a level below optimum, a condition which could be resolved by providing adequate working space under one roof - a building which integrates these offices and allows for an easy flow of information and communications to take place. Efficiency is increased, services provided to the county increase, and residents benefit.

Because of increases in population, the county has had to expand many of its governmental services in order to adequately serve residents. This expansion has had to occur within present space restrictions, which make working conditions almost unbearable. Several departments share one office, each performing a different function. With the projected increases in population, conditions can only grow worse. Even those offices originally created because of coal development now find it difficult to adequately function under present conditions.

In addition, facilities for the County Sheriff's Department are not only crowded, but the present facility itself is outdated and inadequate. Besides offering substandard conditions for prisoners, the current cell block arrangement presents potential dangers both to Sheriff personnel and the prisoners themselves. The cell block arrangement exposes the jailer to all prisoners at any time the cell door is open. Facilities for prisoners are inadequate and cramped. Currently, it is becoming more and more difficult to deal with the number of prisoners brought into the jail. This is primarily because as the population of the county increased, the jail has not. Thus, a building designed to house a 1930 Mercer County Population is having defficulty meeting the demands placed upon it in 1979.

County Road 13 Improvements. Grading and gravelling 10 miles of count.y road south of Zap.

County Road 27 Improvements. Grading and gravelling 8 miles of county road north of Hazen.

County Road 37 Improvements. Grading and gravelling seven miles of county road northwest of Stanton.

County Road I Improvements. Grading and gravelling three miles of county road northwest of Golden Valley. 
County Road 5 Improvements. Grading and gravelling 16 miles of county road south of Golden Valley.

County Road 13 Improvements. Grading and gravelling 12 miles of county road south of Zap.

County Road 5 Improvements. Grading and gravelling thirteen miles of county road north of Golden Valley.

Lewis and Clark Trail. Surfacing of 23 miles of County Road 10.

County Road 27 Improvements. Surfacing of 4 miles of county road north of Hazen. 


\title{
PROPERTY NEEDS FOR HOUSING AND PUBLIC FACILITIES
}

\author{
The City of Beulah
}

\section{Housing Needs}

Experience has shown that of the new housing units locating in the area approximate percentage of demand are as follows: $45 \%$ single family housing, $45 \%$ mobile homes, and $10 \%$ apartments. With this in mind, the projected housing demand was translated into acreage requirements for each year less the property that has already been permitted for construction or is under construction. Therefore, the associated land requirements to meet housing demand is as follows:

$\begin{array}{ccc}\text { Year } & \begin{array}{c}\text { Number of } \\ \text { Units }\end{array} & \begin{array}{c}\text { Additional } \\ \text { Acreage Required }\end{array} \\ 1980 & 109 & 7 \text { acres } \\ 1981 & 159 & 22 \text { acres } \\ 1982 & 169 & 31 \text { acres }\end{array}$

Land that is already available for development has been excluded from additional acreage requirements.

\section{Public Facilities}

Dry Dams. The city will need to acquire approximately 100 acres of land wither through flood easements or through direct land acquisition behind the four drylams. It is felt that outright acquisition is preferred in order to avoid future problems with affected land owners and to provide public access and open space. Since this property is marginal farmland, the estimated cost for acquisition is approximately $\$ 50,000$. 
Bike Path. The city will not need acquire any land for the construction of Phase I of the Beulah Bike Path since a public right-of-way already exists to accomodate this facility. Pháse II land requirements are not known at this time.

Storage and Maintenance Facility. The City of Beulah would need approximately one acre for the development of this facility at an anticipated cost of approximately $\$ 4,000$. This land would need to be located in or very near to the city.

Neighborhood Playgrounds. Two areas of approximately $1 / 2$ acres each will need to be acquired to provide land for playgrounds in newly developed areas. The estimated total cost of this property is $\$ 8,000$.

Parking Lots. Two areas need to be acquired for development of parking lots of approximately one acre each at an estimated total cost of $\$ 30,000$. At least one of these areas has a vacant building on it which needs to be removed.

Softball Diamonds. Approximately three acres will be needed for provision of two softball diamonds. This land can be in the flood plain on the south side of the city. The estimated land acquisition cost for this project is $\$ 3,000$.

Water Line Extension South of Beulah. While there may not be land acquisition requirements for this project, the City may nded to acquire easements. Costs associated with easement acquisition has not been estimated.

Hockey Rink. There are no land acquisition requirements associated with this project since the city already has land available for this purpose.

Joint Airport. The land acquisition requirements for this project is approximately 160 acres. Since no negotiations have been undertaken it is not determined what the cost of this land would be. This 1 and is in an old underground mine area that has subsided. It is of marginal use as. rangeland.

Golf Course Improvements. No land acquisition required. 
Improvements at Beulah Bay. No land acquisition required.

Additional Water Storage. No land acquisition required.

Highway Overpass. No land acquisition required. 


\section{PROPERTY NEEDS FOR HOUSING AND PUBLIC FACILITIES}

The City of Golden Valley

Housing Needs

The city of Golden Valley will need more land for the development of housing. The percentage of housing types needed is anticipated to be approximately $50 \%$ permanent single family construction and $50 \%$ mobile homes. The following is an estimate of the land needed for new homes:

$\begin{array}{lll}\text { Year } & \text { Additional Housing Needed } & \text { Additional Land Needed } \\ 1980 & 22 & 4 \text { acres } \\ 1981 & 31 & 6 \text { acres } \\ 1982 & 33 & 7 \text { acres }\end{array}$

Therefore, it is estimated that approximately 17 acres of new 1 and for development needs should be available for the next three years.

\section{Public Facilities}

Street Paving. The city will not need to acquire streets to accomplish this project since the public streets already exist. However, any new developments other than mobile home courts will require dedication of appropriate streets and rights-of-way.

Community Center. No land acquisition will be necessary to accomplish this project since the city currently owns property to locate this facility. 
Waste water Treatment Facility. The city will need to acquire approximately 5 acres of land for the addition of a third cell. The cost of land for this project is not eligible for funding from EPA. The estimated acquisition cost of this 1 and is $\$ 5,000$. This land is in use as cropland at the present.

Basketbal1 and Tennis Courts. There are no land acquisition needs associated with this project.

Sidewalk Improvements. There are no land acquisition needs associated with this project. 


\section{PROPERTY NEEDS FOR HOUSING AND PUBLIC FACILITIES \\ City of Hazen}

\section{Housing Needs}

The following assumptions, based on historical trends of land development in Hazen, were used to calculate future land use requirements for housing and public facilities and services.

1) That the present ratio of streets and alleys to incorporated area will continue - $22 \%$.

2) That $3 \%$ of the land in Hazen will be utilized as park and recreational. land.

3) That the average single family lot will continue to be 12,000 square feet:

4) That the average mobile home lot will continue to be 6,000 square feet.

5) That the $50 / 50$ building ratio of single family and apartment housing units to mobile homes will continue until a stable population is reached.

1

"Population Projections and Land Use Requirements", Hazen City Planning Office, August, 1977 .

According to the Housing Estimates Table contained in the Housing Needs section of this plan, 484 additional housing units will be needed to accomodate the growth from coal development during the next three years. The following table records the acreage needed for housing, 1980-1982.

\section{City of Hazen Housing Land Requirements}

Year

1980

1981

1982

Total

\section{Acreage}

56

36

8 


\section{Public Facility Needs}

In addition, it is anticipated that .9 of an acre will be acquired as part of the west Hazen access road, .5 of an acre will be required for downtown parking improvements, easements totaling . 4 of an acre will be needed for the west Hazen sewer bypass, and 2 acres will be acquired for the municipal land fill development. 
PROPERTY NEEDS FOR HOUSING AND PUBLIC FACILITIES

Pick City

Housing Needs

Adequate space exists within the Pick City limits to accomodate future demand for housing development.

Public Facilities

.1 of an acre would be required for construction of a city shop/ office. .1 of an acre would be required to complete the proposed recreation improvements. 
PROPERTY NEEDS FOR HOUSING AND PUBLIC FACILITIES

City of Stanton

Housing Needs

The following assumptions were used to calculate future land use requirements for housing in Stanton.

1) $25 \%$ of developable land will be utilized as streets and alleys.

2) The average single family lot will be 10,000 square feet.

3) The average mobile home lot will be 6,000 square feet.

4) $50 \%$ of the housing units added to the city"s housing supply during the next three years will be mobile homes.

According to the Housing Estimates Table contained in the Specific Needs for Housing, Public Facilities, and Public Services Section of this plan, 29 additional housing units will be needed to accomodate growth during the next three years. The following table records the acreage needed for housing, 1980-1982.

\section{City of Hazen Housing Land Requirements}

$\underline{\text { Year }}$

1980

1981

1982

TOTAL
Acreage

5.1

.2

0

5.3 
Public Facilities

The city shop/office would require .25 of an acre for a building site. Approximately 45 acres of 1 and will be required as easement for the transmission line and substation. . I of an acre would be required for an additional city well. Approximately 1 acre will be required for easements for water and sewer expansion. 


\title{
PROPERTY NEEDS FOR HOUSING AND PUBLIC FACILITIES
}

\author{
The City of Zap
}

\section{Housing Needs}

The City of Zap will need more land for the development of housing. While there is some land already deyeloped in Zap for housing, this property has been subtracted from the following projections of land needed for additional housing:

\begin{tabular}{lrr} 
Year & $\begin{array}{c}\text { Additional Housing } \\
\text { Needed }\end{array}$ & $\begin{array}{l}\text { Additional } \\
\text { Land Needed }\end{array}$ \\
\cline { 2 - 3 } 1980 & 38 & 5 acres \\
1981 & 39 & 7 acres \\
1982 & 52 & 11 acres
\end{tabular}

Therefore, approximately twenty three additional acres will be needed for development of housing in Zap in the next three years.

\section{Public Facilities}

Waste Water Treatment Facilities. This facility will require approximately 5 acres of land to locate an additional cell: The estimated cost of this land is $\$ 7500$. Land acquisition for waste water treatment facilities is not eligible for funding under EPA programs. The land needed for development of this facility is currently being used as grazing land.

Municipal Water Supply Wel1. Approximately two acres of land will be needed for this project to locate a new well and to transport the water to existing water lines.

Community Center and Storage Facility. No land acquisition requirements are associated with this facility. 
Softball Diamond. Approximately two acres of land needs to be acquired for the development of this facility at an estimated cost of $\$ 5,000$.

Flood Control Project. No land acquisition is associated with this project.

Skating Rink. No 1 and acquisition is associated with this project.

Sidewalk Improvements. No land acquisition requirements are associated with this project.

Water Treatment Plant. The city will neeld to acquire approximately $1 \frac{1}{2}$ acres of land for the development of this facility at an estimated cost of $\$ 5,000$. 


\section{PROPERTY NEEDS FOR HOUSING AND PUBLIC FACILITIES}

Mercer County

Housing Needs.

Refer to the housing needs section for the individual cities.

Public Facilities

Approximately . 5 of an acre will be required for construction of the Human Services Center and County Jaill. 
LAND ACQUISITION

The City of Beulah

Housing Needs

It is anticipated that no land needs to be acquired by the local or state government for the development of private housing. However, the city has applied to the Department of HUD for land acquisition for eight units of public housing in accordance with an approved Housing Assistance Plan.

\section{Public Facilities Needs}

Dry Dams. The city will need to acquire the land associated with this project by a preferred method of negotiation with owners on an appraised value of the property. If this fails, it would be possible to initiate the local government's condemnation powers.

Bike Path. NA

Storage and Maintenance Facility. This land should be acquired by negotiation and direct purchase from the owner.

Neighborhood Playgrounds. The method of land acquisition for these projects should be through negotiation and purchase from the owner.

Parking Lots. Land acquisitions for these facilities should be through negotiation with the owner and subsequent purchase.

Softball Diamonds. Land acquisition for these facilities should be through negotiation with the owner and subsequent purchase. 
Water Line Extension South of Beulah. Easements and Land Acquisition for this property should be by negotiation with the owners and subsequent purchase. If negotiations fail, acquisition could be accomplished by the local governments condemation powers.

Hockey Rink. NA

Joint Airport. Land acquisition for this project should be accomplished by negotiation with owner and subsequent purchase.

Golf Course Improvements. NA

Improvements at Beulah Bay. NA

Additional water Storage. NA

Highway. Overpass. NA 


\section{LAND ACQUISITION}

The City of Golden Valley

Housing Needs

It is anticipated that there will be no need for the local or state government to acquire land for additional housing since private developers should be able to fill this need.

\section{Public Facilities Needs}

Street Paving. NA

Waste Water Treatment Facility. The city should use a preferred method of land acquisition by negotiation with the owner of the property needed to accomplish this project. If negotiations fail, the property may be acquired by the city's power of emminent domain.

Basketball and Tennis Courts. NA

Sidewalk Improvements. NA 


\title{
LAND ACQUISITION
}

\author{
City of Hazen
}

It will be necessary to acquire land in four of the projects outlined in this plan. In all instances, property owners will be made an offer by the city regarding purchase of rights-of-way on property. In the event that a settlement is not reached, the city will proceed with condemation procedures in accordance with Sections40-22, 40-39, and 40-62. of the North Dakota Century Code. 


\section{LAND ACQUISITION}

Pick City

No land acquisition is required. 


\section{LAND ACQUISITION}

City of Stanton

It will be necessary to acquire easements in two of the projects outlined in this plan - modification of the electrical source and expansion of water and sewer. In all instances, property owners will be made an offer by the city regarding purchse of rights-of-way. In the event a settlement is not reached, the city will proceed with condemnation procedures in accordance with Sections 40-22 and 40-39 of the North Dakota Century Code. 


\section{LAND ACQUISITION}

The City of Zap

\section{Housing Needs}

It is anticipated that no land needs to be acquired for the development of housing in Zap since private developers have demonstrated the capacity to provide land in a timely manner.

\section{Public Facilities Needs}

Waste Water Treatment Facilities. The city of Zap should use a preferred method of 1 and acquisition by negotiation with the owner. If negotiations fail, the city may exercise its powers of condemation.

Municipal Water Supply Well. The City of Zap should use a preferred method of land acquisition by negotiation with the owner. If negotiations fail, the city may exercise its powers of condemnation.

Community Center and Storage Facility. NA

Softball Diamond. Method of land acquisition for this project should be through negotiation with the owner.

Flood Control Project. NA

Skating Rink.. NA

Sidewalk Improvements. NA

Water Treatment Plant. The City of Zap should use a preferred method of land acquisition by negotiation with the owner. If negotiations fail, the city may exercise its power of condemation. 


\title{
IAND ACQUISITION
}

\author{
Mercer County
}

As land is available at the present court house site, no land acquisition is required for the Human Resource Center/County Jail project. No land acquisition is necessary for completion of the county road improvements. 


\section{ESTIMATE OF ASSISTANCE}

The City of Beulah

Housing Needs NA

\section{Public Facilities}

The following estimates of assistance needed to provide public facilities identified in this plan are as follows:

\begin{tabular}{|c|c|c|}
\hline Project & Acquisition & Development \\
\hline Dry Dams & $\$ 50,000$ & $\$ 1,050,000$ \\
\hline Bike Path & $\mathrm{NA}$ & 52,000 \\
\hline $\begin{array}{l}\text { Storage and Maintenance } \\
\text { Facility }\end{array}$ & $\$ 4,000$ & 210,000 \\
\hline Neighborhood Playgrounds & $\$ 8,000$ & 52,000 \\
\hline Parking Lots & $\$ 30,000$ & 50,000 \\
\hline Softball Diamonds & $\$ 3,000$ & 87,000 \\
\hline $\begin{array}{c}\text { Water Lines South } \\
\text { of Reulah }\end{array}$ & $\$ 5,000$ & 95,000 \\
\hline Hockey Rink & NA & 40,000 \\
\hline Joint Airport & -- & $\$ 2,700,000$ \\
\hline Golf Course & NA & 100,000 \\
\hline $\begin{array}{l}\text { Improvements at Beulah. } \\
\text { Bay }\end{array}$ & $\mathrm{NA}$ & 100,000 \\
\hline Additional Water Storage & NA & 600,000 \\
\hline Highway Overpass & NA & $\$ 2,000,000$ \\
\hline
\end{tabular}




\section{ESTIMATE OF ASSISTANCE}

The City of Golden Valley

Housing Needs $\quad$ NA

\section{Public Facilities}

The following estimates of assistance needed to provide public facilities are as follows:

\begin{tabular}{|c|c|c|}
\hline Project & Land Acquisition & Development \\
\hline Street Paving & NA & $\$ 520,000$ \\
\hline Community Center & NA & $\$ 200,000$ \\
\hline $\begin{array}{l}\text { Waste Water Treatment } \\
\text { Facility }\end{array}$ & $\$ 5,000$ & $\$ 75,000$ \\
\hline $\begin{array}{l}\text { Basketball and Tennis } \\
\text { Courts }\end{array}$ & NA & $\$ 60,000$ \\
\hline Sidewalk Improvements & NA & $\$ 80,000$ \\
\hline
\end{tabular}




\section{ESTIMATE OF ASSISTANCE}

\section{City of Hazen}

The following table estimates the amount of financial assistance which will be necessary to implement the housing, public facilities, and public services plan for the city of Hazen.

\section{City of Hazen Financial Assistance Estimates}

$\underline{\text { Project }}$

West Hazen Access Road and

Drainage Improvements

Downtown Parking Improvements

Bike Trail Development

West Hazen Sewer Bypass

Sewer Main Replacement

City Landfill Development

Additional City Well

Completion of Water, Sewer and Streets in New Subdivision 208,000

Joint Airport

$\$ 2,700,000$

TOTAL

\section{Cost}

$\$ 325,000$

$\$ 100,000$

$\$ 10,000$

$\$ 20,000$

$\$ 40,000$

$\$ 15,000$

$\$ 50,000$ 
ESTIMATE OF ASSISTANCE

\section{Pick City}

The following table estimates the amount of financial assistance which will be necessary to implement the housing, public facilities, and public services plan for Pick City.

\section{Pick City Financial Assistance Estimates}

\section{Project}

Street Grading and Paving

Sewer and Water Lines to New Areas

City Shop and Offices

Recreation Facilities

TOTAL

\section{Cost}

$\$ 450,000$

$\$ 65,000$

$\$ 50,000$

$\$ 50,000$

$\$ 615,000$ 
ESTIMATE OF ASSISTANCE

City of Stanton

The following table estimates the amount of financial assistance which will be necessary to implement the housing, public facilities, and public services plan for the city of Stanton.

\section{City of Stanton Financial Assistance Estimates}

Project

City Shop/Office

Pump/Motor for North

Lift Station

Modify Electrical Source

Second City Well

Expansion of Water and Sewer

Increase Size of South

Lift Station

TOTAL
Cost

$\$ 100,000$

$\$ \quad 6,000$

$\$ 200,000$

$\$ 25,000$

$\$ 100,000$

$\$ 30,000$

$\$ 461,000$ 


\section{ESTIMATE OF ASSISTANCE}

The City of Zap

Housing Needs NA

\section{Public Facilities}

The following estimates of assistance needed to provide public facilities are as follows:

Project

Waste Water Treatment Facilities

Municipal Water Well

Community Center and Storage Facility

Softball Diamond

Flood Control Project

Skating Rink

Sidewalk Improvements

Water Treatment Plant
Land Acquisition

Development

$\begin{array}{ll}\$ 7,500 & \$ 97,500 \\ \$ 5,000 & \$ 105,000 \\ \text { NA } & \$ 250,000 \\ \$ 5,000 & \$ 25,000 \\ \text { NA } & \$ 25,000 \\ \text { NA } & \$ 20,000 \\ \text { NA } & \$ 20,000 \\ \$ 5,000 & \$ 245,000\end{array}$




\title{
ESTIMATE OF ASSISTANCE
}

\author{
Mercer County
}

The following table estimates the amount of financial assistance which will be necessary to implement the housing, public facilities, and public services plan for Mercer County.

\section{Mercer County Financial Assistance Estimates}

Project

Human Services Center

County Jail

Road Improvements

Lewis \& Clark Trail

Surfacing

TOTAL
Cost

$\$ 400,000$

400,000

$5,000.000$

$2,500,000$

$\$ 8,300,000$ 


\section{Energy Development Board Staff}

Robert Stroup . . . . . . . . . Executive Director

Gary Anderson . . . . . . . . . Energy Analyst

Al DeKrey . . . . . . . . . . Planner-Coordinator

Bill Mrdeza . . . . . . . . . . Associate Planner

John Rogers . . . . . . . . . . Planner-Coordinator

Vivian Roehrich . . . . . . . . . Office Manager

Deborah Prock . . . . . . . . . Secretary

Larry Weil. . . . . . . . . . . Intern 